\title{
TEORETICKÉ STUDIE
}

\author{
DVACET LET ČESKÉHO ŠKOLSTVÍ \\ OPTIKOU TEORIÍ ZMĚNY VZDĚLÁVÁNÍ \\ V POST-SOCIALISTICKÝCH ZEMÍCH
}

\section{DAVID GREGER}

Anotace: Studie podává kritický prehled teorií post-socialistické transformace vzdèlávání (M. Fullan, C. Birzea) a přináší návrh na členění a chápání vývoje školství od roku 1989. Ze srovnání teorií vyvstává vždy otázka, zda je možné považovat post-socialistickou transformaci za ukončenou, na kterou v závěru textu přinášíme vlastní odpověd'. Stejně tak se kriticky vypořádáváme s konceptem druhé tranzice v zemích střední a východní Evropy. V neposlední raadě je text vztažen predevším $k$ dvaceti letům vývoje českého školství, který vzhledem ke zhoršujícím se výsledkưm českých žáků považujeme za neutěšený.

Abstract: In this paper we critically analyze theories of educational change in postsocialist transformation (theories of M. Fullan and C. Birzea) and we propose our own theoretical framework based on the reconciliation of the two theories. In this way we want to answer the key question - whether the post-socialist transformation came to its end. We argue against the idea of second transition in Central and Eastern European Countries proposed by some authors. Last but not least, we take as a case study the example of 20 years reform of educational change in the Czech Republic, which shows large declines in students' knowledge and skills, and thus turns out as unsuccessful story of reform.

Klíčová slova: post-socialistická transformace, teorie změny vzdělávání, vzdělávací politika, Česká republika

Key Words: post-socialist transformation, education change, education policy, Czech Republic 


\section{1 ÚVOD}

V této studii' se chci s odstupem více než dvaceti let od Sametové revoluce podívat na vývoj vzdělávání v Česku. Především ve druhé polovině devadesátých let 20. století se objevily první snahy o reflexi mnohdy živelných změn $v$ rámci společenské transformace a o teoretické uchopení procesu transformace $s$ cílem lépe porozumět dosavadnímu vývoji a prípadně jej lépe předvídat a korigovat žádoucím směrem. $V$ tomto období, kdy se v post-socialistických společnostech tvořila většina strategií rozvoje a také „nových“ koncepcí vzdělávání, byla teoretická reflexe proběhlých změn a na ní založený výhled základem tvorby oněch strategií. Navíc světový zájem o dění v regionu střední a východní Evropy byl zejména v první dekádě po politickém převratu veliký, a tak se studie popisující probíhající změny nebo studie nabízející teoretickou reflexi změn v regionu těšily zvláštnímu zájmu nadnárodních organizací, které tyto práce také mnohdy iniciovaly ( $v$ oblasti vzdělávání především studie Světové banky - Berryman 2000 a Fiszbein 2001 a Rady Evropy - Birzea 1994). Téma vývoje vzdělávání po roce 1989 se tak stalo zásadním tématem srovnávací pedagogiky a pomohlo k jejímu obnovení a rozvoji i v ČR. Touha po informacích zvenčí otevírala možnosti zahraničních publikací a především kontaktů s významnými kolegy českým pedagogům, stejně tak jako v jiných oblastech sociologům, politologům, ekonomům apod. Řada významných českých pedagogů tak psala studie o vývoji a změnách v Československu po obnovení demokracie (jako príklad uved'me především J. Kotáska, V. Pařízka, J. Kovařovice, J. Průchu, E. Walterovou, J. Kalouse, S. Štecha aj.). Je patrné, že se však jedná především o pedagogy pražské, kteří byli centru dění nejbliže, a zájem o vývoj školství jako systému má tak velkou tradici především v Praze.

Stejně tak k reflexi polistopadových změn přispěli kolegové navrátivší se z emigrace (zde významně především L. Čerych, J. Mestenhauser) či významní zahraniční výzkumníci s kořeny v ČR (W. Mitter). V první polovině devadesátých let 20. století tak vznikla celá řada studií popisujících vývoj školství v Československu (či později ČR) i v dalších zemích v regionu po pádu železné opony. Nicméně tím, jak zájem o popis vývoje vzdělávání v regionu přicházel zvenčí a často šlo o srovnávací analýzy zahrnující vícero prípadů jednotlivých zemí, byly tyto práce převážně publikovány anglicky (např. Průcha; Walterová 1992). V českém jazyce je reflexí onoho

1 Tato studie je výstupem rešení projektu Centra základního výzkumu školního vzdělávání (LC06046) financovaného Ministerstvem školství, mládeže a tělovýchovy České republiky. Případnou korespondenci k tomu textu posílejte na adresu david.greger@pedf.cuni.cz. Chtěl bych poděkovat všem, kteři významnou měrou přispěli $\mathrm{k}$ mému přemýšlení o transformaci vzdělávání v post-socialistických zemích. Na prvním místě Elišce Walterové, se kterou jsme 3 roky vedli projekt srovnávající vývoj školství v zemích Visegrádu. Stejně tak jí děkuji za důkladné pročtení rukopisu studie a cenné připomínky k jejímu dopracování. Nelze nevzpomenout ani na již zesnulého Jiřího Kotáska, který celý projekt inicioval a se kterým jsem mohl hovořit o jeho prvních návrzích teoretického uchopení vývoje po roce 1989. Dále chci poděkovat všem kolegům, kteří s námi na projektu srovnávání v zemích Visegrádu spolupracovali (Beata Kosová a Štefan Porubský ze Slovenska, Gábor Halász z Mad’arska, Andrzej Janowski z Polska), i dalším kolegům ze zahraničí - César Birzea, Wolfgang Mitter a Alexander Wiseman. 
vývoje znatelně méně. Mezi poslední pak patří především práce J. Kotáska (Kotásek $2005 a$, b), na niž v tomto textu dále navazujeme. Reflexe vývoje v českém jazyce je o poznání obtižnější, nebot kritických čtenářủ je více, jistou roli hrají i odlišné interpretace a pozice aktérů změn vzdělávání na počátku devadesátých let 20. století. Nicméně o to důležitější je proces změn reflektovat v domácím prostředí, protože reflexe nedávného vývoje, jeho úspěchů i neúspěchů, přispívá k lepšímu chápání současnosti a v duchu rčení historia magistra vitae snad může vést i k poučení.

S tímto cílem jsme také v rámci projektu Centra základního výzkumu školního vzdělávání iniciovali komparaci vývoje vzdělávání po roce 1989 do současnosti. První studie jsme čtenárumm představili v anglickém čísle časopisu Orbis scholae 2/2007 a celá práce vyvrcholila publikací vydanou v zahraničí (Greger; Walterová, v tisku). Otázka teoretického uchopení transformace vzdělávání, jak jsme ji představili v uvedeném čísle časopisu Orbis scholae, otevřela širší diskusi, která se na stránkách časopisu dále rozvíjela. $V$ čísle $2 / 2008$ na uveřejněné texty reagoval C. Birzea (2008) a v čísle 2 minulého ročníku pak do diskuse dále přispěl W. Mitter (2010). Všechny tyto texty jsou však v anglických číslech Orbis scholae. Jediný český text k transformaci vzdělávání v zemích Visegrádu jsme přinesli v prvním čísle časopisu Orbis scholae (Walterová; Greger 2006). $V$ této studii proto představím některé teoretické reflexe transformace $v$ post-socialistických zemích a s jejich pomocí se podívám na vývoj českého školství a jeho výsledky.

\section{NEUTĚŠENÉ VÝSLEDKY ČESKÉHO VZDĚLÁVÁNÍ PO 20 LETECH „REFOREM“}

Reforma celého vzdělávacího systému (whole-system reform, dále používám stručné označení systémová reforma) je nepochybně náročnější než implementace dílčích projektů nebo inovací, které však zasáhnou pouze malé procento škol a žáků. Pozitivní príklady změny $v$ malém měřítku nejsou zpravidla přenositelné na celý vzdělávací systém, a tak systémová reforma vyžaduje mnohem větší úsilí a promýšlení. M. Fullan a B. Levin (2009) ukazují na príkladu kanadské provincie Ontario, jaké by měla mít taková reforma vlastnosti. Vycházejí přitom ze zkušeností $z$ implementace reformy $v$ této provincii od roku 2003. Úspěšnost reformy přitom dokládají tím, jak se zlepšily výsledky tamních žáků v matematice a čtenářské gramotnosti, nárůstem počtu absolventů středních škol, ale také pozitivním naladěním učitelů a ředitelů škol a také veřejnosti. Měřítkem úspěšnosti reformování vzdělávání v ČR by měly být především výsledky vzdělávání na straně žáků (nejen kognitivní, ale i postoje žáků ke vzdělávání aj.), případně postoje rodičů a dalších prímých aktérů vzdělávání, tj. učitelů a ředitelů škol. Jak si v tomto ohledu tedy stojí český vzdělávací systém?

Je symptomatické, že nebýt účasti ČR v mezinárodních výzkumech, o vývoji výsledků vzdělávání českých žáků (znalostí, dovedností, kompetencí či postojů) bychom nevěděli téměř nic. Vlastní data o znalostech a dovednostech českých žáků MŠMT nesbírá, prípadně data, jež sebralo, s tímto záměrem cíleně nevyhod- 
nocuje (např. pilotní testování žáků v 5. a 9. ročníku v rámci projektu ESF Kvalita I.). A tak jen z mezinárodních výzkumů TIMSS $(1995,1999$ a 2007) a PISA (2000, 2003, $2006,2009)$ víme, že se výsledky českých žáků v čase zhoršují - a to nejen relativně (ve vztahu k ostatním zemím, které se výzkumu zúčastnily), ale také absolutně. Nedávno zveřejněná zpráva společnosti McKinsey o stavu českého regionálního školství tak zvolila název Klesající výsledky českého základního a středního školství: fakta a řešení a odhadla, jak vysoké finanční ztráty pokles vzdělávání pro českou společnost znamená (autoři odhadli, že snižující se znalosti žáků v testech TIMSS mohou mít za následek pokles HDP do roku 2050 o $11 \%$ - viz McKinsey 2010, s. 27). Ještě před zprávou McKinsey jsme se přičinami neutěšených výsledků českých žáků zabývali při analýze naplňování cílů Bílé knihy (Straková a kol. 2009), kde jsme mimo jiné upozornili na skutečnost, že v Bílé knize, jakkoliv navrhovala řadu opatření (z nichž mnohá nebyla realizována), nebyly stanovené cíle operacionalizovány tak, aby úspěšnost jejich naplnění mohla být jednoznačně vyhodnocena. ${ }^{2}$ Navíc úředníky MŠMT byla řada opatření splněna zcela formálně - zahrnutím do zákona či upřesněním ve vyhlášce. Vztah $\mathrm{k}$ výsledkům žáků a realizace navržených opatření ve škole nebyly promýšleny. Školám nebyla dána podpora k účinné implementaci nově zaváděných opatření. Jak ukážu dále $v$ textu, právě implementace reforem je zásadním problémem nejen u nás, ale i v dalších vzdělávacích systémech.

V další části textu představím dvě stěžejní teoretické reflexe vývoje vzdělávání v post-socialistických zemích a $s$ jejich pomocí se podívám na vývoj v ČR a neúspěch reforem.

\section{MODEL TŘÍ-I MICHAELA FULLANA}

Michael Fullan, známý odborník na teorii změn a jejich implementaci ve vzdělávání, popsal svůj model tří-I (triple-I model) v práci The New Meaning of Educational Change (Fullan 2007). Jedná se o popis tří fází (tř̌i l) změny ve vzdělávání.

Fáze I: Iniciace - jedná se o počáteční fázi, která vede k rozhodnutí provést určitou změnu.

Fáze II: Implementace - zahrnuje první zkušenosti se zaváděním myšlenky reformy do praxe. Dle Fullana se jedná o první 2-3 roky zavádění.

Fáze III: Institucionalizace - jinak také nazývána "pokračování" (continuation) označuje skutečnost, zda se změna uchytí a zůstane zachována a zabudována do současného systému jako její integrální součást, nebo zda dojde k návratu k původnímu stavu.

2 Totéž platí pro kurikulární reformu. Také ta byla zahájena a nebyly stanoveny indikátory, které by umožnily vyhodnotit, zda reforma je, či není úspěšná. Ty se začaly (a není divu, že velmi obtížně) hledat až po několika letech od jejího spuštění. Když Michael Fullan (2007) ve své knize uvádí príiklady úspěšných reforem v Anglii a Ontáriu, nevolí je proto, že by se mu líbily nutně jejich prvky (reforma v Anglii i Ontáriu stavěla na jiných základech i doporučeních), ale proto, že dosáhly cílů, které se stanovily - tj. zlepšení výsledků žáků. 
Podstatné opět je, že v centru Fullanova modelu jsou výsledky žáků, které jsou cílem, a tedy i měřítkem úspěšnosti reforem. Jednotlivé fáze Fullan dále rozpracovává a popisuje aktéry, kteří v jednotlivých fázích hrají klíčovou roli, a faktory, jež ovlivňují úspěšnost zvláště implementace (viz Fullan 2007, s. 64-121). Je užitečné seznámit se $s$ celou koncepcí $M$. Fullana zvláště pro ty, kdo se zabývají vzdělávací politikou a implementací reforem. Také důkladná analýza reforem v Anglii a Ontáriu v téže knize nabízí inspirující příklady efektivního rízení změny ve vzdělávání.

Jádrem sdělení tohoto textu však není, jak by měla být prováděna reforma, ale je to spíše ohlédnutí se zpět. Z tohoto pohledu je pak důležité, že Fullan s dalšími kolegy použil tento model na analýzu vývoje vzdělávání v post-socialistických zemích (Polyzoi; Fullan; Achnan 2003). Kniha zahrnuje případové studie Ruska, České republiky, Mad'arska, Rumunska a východního Německa, které využívají Fullanův model k popisu více než deseti let vývoje vzdělávání od pádu železné opony.

Nicméně při aplikaci modelu tří-I došli již samotní autoři kapitol k tomu, že model není zcela vhodný $\mathrm{k}$ popisu spontánních změn, které se udály v post-socialistických zemích na počátku devadesátých let 20. století. Halász (2003) v kapitole o mad’arském vývoji zdůrazňuje, že ve Fullanově modelu je změna chápána jako předem plánovaná $s$ jasně vytčenými cíli a jako řízený proces. Vývoj v rané fázi post-socialistické transformace se odehrával spiše spontánně, změna tak byla výstupem ne předem plánovaného, ale zcela otevřeného procesu bez jasných cílů. Je skutečností, že mnohé změny především na počátku roku 1990 byly prováděny okamžitě, jako negace minulého režimu, nikoli však $s$ jasnou vizí alternativních řešení nebo promyšleným způsobem implementace, jak by vyžadoval Fullanův model. Stejně tak Čerych (1995) uvádí, že změny v regionu střední a východní Evropy byly provedeny takovou rychlostí, že to $v$ západním světě nemělo obdoby. Reformy jsou standardně připravovány a implementovány $v$ rádu let, nicméně mnohé změny $v$ postsocialistické transformaci se udály během několika měsíců, či nejdéle do jednoho roku. Také další autoři, kteří použili Fullanův model, potvrzují, že se nehodí pro popis rané fáze transformace. Polyzoi a Černá (2003) v kapitole o vývoji v České republice píší, že „Fullanův model, jakkoliv bohatý na detaily, nedokáže postihnout revoluční charakter prováděných změn". A Mays et al. (1996) také při analýze vývoje v ČR docházejí rovněž k závěru, že Fullanův model se hodí pro popis „plánovaných reforem a změn, které jsou řizeny od svého počátku přes implementaci a jejich další kontinuitu“. Nicméně, jak autorky uvádějí, takto se změny v ČR neodehrávaly. Krom spontánního charakteru změn autorky ještě zdůrazňují, že koncept plánování byl navíc zdiskreditován socialistickou podobou plnění plánů pětiletek. Plánování tak nechybělo jen $v$ důsledku charakteru a rychlosti změn, ale jaksi programově, jako protiklad ke stálému plnění a překonávání norem a plánů socialistického hospodářství.

Fullanův model změn a reforem vzdělávání, který vznikl v Severní Americe a byl testován na prípadech především západních demokracií s dlouholetou nepřerušenou tradicí, byl aplikován na vývoj školství ve „Východním bloku“ po skončení studené války. Tento test však nechal vyniknout právě tomu, čím se změny v post-revoluční době lišily od plánovaných změn a reforem v tradičních systémech. 
To je důležité si uvědomit. Je to i jeden z důvodů, proč nepřijímám tezi o druhé transformaci, kterou ve svých textech uvádějí Halász (2007) a Birzea (2008) na stránkách předchozích čísel časopisu Orbis scholae. Za druhou tranzici ${ }^{3}$ tito autoři považují integraci zemí Východního bloku do Evropské unie. Druhou transformací dle těchto autorů je tedy evropská integrace. Birzea ve své práci odkazuje na práci De Sota a Andersona, kteří uvádějí, že zatímco post-socialistická transformace trvala 10-15 let, nová fáze, kterou nazývaji „post-tranzice“, bude ještě delší a dramatičtější. V duchu těchto a dalších prací pak Birzea chápe druhou tranzici jako vyrovnání se především ekonomické úrovni rozvinutých zemí „evropské patnáctky".

S Birzeou i Halászem souhlasím v tom, že vstup do EU znamená nové výzvy a otevírá dalši řízené procesy změny. Takových transformací můžeme však identifikovat celou řadu - kromě evropské integrace např́klad také transformace ke společnosti vědění. Tyto transformace se však již týkají nejen „nových členských státü“ EU, ale i původních členů, stejně tak jako i dalších zemí světových regionů. Svým charakterem jsou to však velké celospolečenské transformace, které jsou dlouhodobé. Postrádají první fázi revolučních rychlých změn, které byly charakteristické pro transformaci post-socialistickou. $Z$ tohoto důvodu dle mého názoru není vhodné mluvit o první (transformace post-socialistické) a druhé („transformace zpět do Evropy“, jak ji nazývá Birzea) transformaci v zemích „Ostbloku“. Obě transformace se zásadním způsobem liší a pouze post-socialistická transformace je unikátní pro tyto zemè.

Přestože proces přistoupení vedl k přijímání mnoha norem EU v kandidátských zemích a určitě proměnil $v$ mnoha ohledech tamní společnosti, ve světle předchozích odstavců je zřejmé, že změny nebyly takového charakteru a rozsahu jako změny po roce 1989. Určitě je možné hovořit o modernizaci či transformaci, nebo o europeizaci, nicméně její prímé srovnání s post-socialistickou transformací dle mého názoru neobstojí.

Zatímco změny $v$ devadesátých letech byly nejen rychlé, ale byly to skutečné změny, které zasáhly všechny školy a učitele, změny zaváděné v procesu přistupování $\mathrm{k}$ EU byly často formální, bez konkrétních dopadů do reality škol. Změny v devadesátých letech byly iniciovány zdola, zatímco změny "vynucené" přístupovými dialogy před rokem 2004 byly často změnami formálními, v pravém slova smyslu tedy o změnu reality ani nešlo. Můžeme si to ukázat na příkladu práv Romů. Jak uvádějí Davidová et al. (2005, s. 45), pro kandidátské země platila přísnější pravidla pro respektování a ochranu menšin než pro členské státy. Kandidátské země tak práva menšin ukotvily ve své legislativě pevněji než řada původních členských států (např. Francie či Řecko). Jak však upozorňují autoři (a ostatně také nálezy Evropského soudu), legislativní ukotvení nevypovídá nic o skutečném stavu a životních podmínkách Romů v ČR a jejich integraci.

3 Oba autoři nehovoří o transformaci, nýbrž o tranzici, my však preferujeme hovořit o transformaci - v návaznosti na dobře vyargumentovanou diskusi významů obou pojmů P. Machoninem 2005, s. 138-142. 
Tento př́klad je jen jedním z mnoha, který však ukazuje důležitou odlišnost raného období, kdy změny byly iniciovány a vyžadovány zdola, a tím také byly přijímány a aplikovány ve školní realitě. Po změnách volali učitelé, rodiče, politici i široká veřejnost. Přestože některé $z$ nich byly nepromyšlené a bez koncepce (bez plánování - jako např. zavedení selekce v podobě víceletých gymnázií, zrušení pedagogických center aj.), jejich realizace byla rychlá a trvalá. Z hlediska Fullanova modelu tak můžeme říci, že fáze iniciace byla charakteristická sdíleným přesvědčením o nezbytnosti změn (např. de-ideologizace obsahů vzdělávání a přepisování učebnic) u mnoha aktérů (učitelů, rodičů, veřejnosti, politické reprezentace). Tím, že mnohé změny měly širokou podporu veřejnosti a především učitelů a ředitelů škol (převážně nově zvolených do svých funkcí), panovala sdílená euforie z otevření možností změnám, jejich implementaci nebylo nutné ani nějak př́liš řídit, stačilo jí jen otevř́t prostor.

Při pohledu na druhou půli devadesátých let a následný vývoj pak je však vidět, že takováto souhra okolností již nebyla (a patrně už nikdy nenastane) a že jakákoliv reforma se musí odpracovat dle Fullanova modelu od zrodu myšlenky či koncepce a její komunikace mezi různými aktéry (iniciace) a pečlivého vysvětlování veřejnosti i pedagogům, přes masivní podporu a nezávislé monitorování implementace (důkladně promýšlené po dobu aspoň 2 let) až po následné vyhodnocení takto zaváděných změn a jejich případné institucionalizace, tj. ukotvení v trvalých strukturách systému vzdělávání. Tento komplex všech tř̌i fází je nesmírně obtížný a v Analýze naplňování cílů Bílé knihy (Straková et al. 2009) jsme shledali, že v ČR zcela chybí. Hovořili jsme o něm jako o strategickém řízení, které je možno spojit s tím, co charakterizuje Fullan ve svém modelu. MŠMT však často při zavádění změn (at' již to byla kurikulární reforma, reforma maturitních zkoušek aj.) jako by chtělo přeskočit fázi iniciace (vymezení a důkladné vysvětlování cílů reforem) a implementace (podpora školám a monitorování úspěšnosti počátečního zavádění) a přistoupit rovnou $\mathrm{k}$ institucionalizaci (legislativnímu ukotvení, nařízení apod.). $\checkmark$ tomto ohledu je Fullanův model velmi prínosný pro chápání neúspěchu reforem vzdělávání v ČR od druhé poloviny devadesátých let 20. století. Zatímco změny $v$ roce 1990 přicházely především zdola, později již byly reformy zaváděny shora, a jak jsme již zdůraznili, ne efektivně, bez strategického řízení a uvádění myšlenek reforem k životu (řádné implementace). Tento přístup navíc patrně zdiskreditoval myšlenku reforem a reformování, které u učitelů i ředitelů škol již a priori vzbuzuje podezření a opatrnost. Podívejme se však na další teoretické uchopení procesu transformace, které má svůj původ v zemích „Východního bloku“.

\section{KONCEPCE POST-SOCIALISTICKÉ TRANSFORMACE VZDĚLÁVÁNÍ CESARA BIRZEY}

Na rozdíl od Fullanova modelu, Cesar Birzea vycházel ze znalosti transformace v Rumunsku po pádu komunismu a popravě Ceausescua. Na rozdíl od Fullanova modelu tak reflektuje revolučnost změn a má větší pochopení pro skutečnost, že 
mnohé změny nebyly nikterak plánovány, prostě se udály. Ve svých pracích pak ukazuje na skutečnost, že šlo o hledání rovnováhy mezi kontinuitou a rozchodem s minulostí, o dilema mezi kontinuitou a změnou. Birzea své práce psal již v první polovině devadesátých let 20. stol. (viz Birzea 1994, 1995 a 1996a,b), a tak jeho reflexe se týkala především raného vývoje. Birzea rozlišuje čtyři fáze post-socialistické transformace. ( $V$ jednotlivých pracích se pojmenování fází mírně liší, nicméně charakter jednotlivých fází je stejný. Zde uvádíme pojmenování fází dle práce Birzea 1996a, uvedené roky trvání jednotlivých fází platí pro př́padovou studii post-socialistického vývoje $v$ Rumunsku.)

Fáze I: De-strukturace (1990), tedy první rok reforem se nesl ve znaku negace vzdělávacího systému minulého režimu.

Fáze II: Stabilizace (1991-1992), představuje fázi nového nastartování a rekonstrukce. Zahrnovala především tvorbu nových zákonných norem a zakotvení provedených změn do legislativní i institucionální oblasti.

Fáze III: Restrukturace (1993-1995), znamená již formulování koherentní systémové reformy vzdělávání, která se zakládá na analýzách stavu školství a dosavadního post-revolučního vývoje. Restrukturace je tak chápána jako formulace reformního návrhu, který by zahrnoval komplexní změnu vzdělávání. Na rozdíl od „živelných" či "spontánních“ změn bez plánů v období de-strukturace je období re-strukturace nastoupením tvorby vzdělávací politiky podobné v západních demokratických společnostech. Tedy již plánování reforem, jak o nich píše Michael Fullan.

Fáze IV: Proti-návrhy reforem (po roce 1993), jakmile byly návrhy systémové reformy předloženy, vznikaly proti-návrhy či alternativní návrhy reforem ze strany vládní opozice či nejrůznějších zájmových skupin.

Na základě komparativní studie post-socialistického vývoje v zemích Visegrádu v našem projektu (viz Orbis scholae číslo 2/2007 a Greger; Walterová, v tisku), jsme došli v př́padě České republiky, Slovenska, Mad’arska a Polska ke shodě, že první dvě fáze jsou typické pro vývoj v našich zemích po pádu předchozího režimu. Stejně tak jsme dospěli k tomu, že po této fázi již dochází k rekonstrukci, jež zahrnuje formulování ucelené systémové reformy. I proto jsme pro náš projekt zvolili členění na čtyři fáze, které jsou inspirovány Birzeovým pojetím v úpravě J. Kotáska pro Českou republiku (blíže viz Kotásek et al. 2004, Kotásek 2005a,b). Připomeňme, že české reflexe pak dále inspirovaly i slovenské autory k popisu transformace ve Slovenském kontextu (Kosová; Porubský 2011).

Úprava J. Kotáska pracovala se všemi čtyřmi fázemi pro př́pad České republiky, přičemž fázi I. nazývá dekonstrukce (1990-1991), fáze II. - parciální stabilizace (1991 - 2000) byla dle Kotáska charakteristická prijímáním ad hoc opatření a analýzami dosavadního vývoje a stavu školství. Již v tomto období vznikla řada programů a návrhů reforem vzdělávání $v$ ČR, které usilovaly o reformu celého vzdělávacího systému (ve smyslu Fullanova "whole-system change", nebo "large-scale reform"), např̀ návrhy skupin IDEA, PAU, NEMES ${ }^{4}$ nebo ministerský program s názvem Kvalita

4 Přehled a vyhodnocení různých návrhů koncepcí rozvoje vzdělávání, které se v ČR především v devadesátých letech 20 . století objevily, včetně i pozdějších návrhů, dosud nebyly zpracovány. 
a odpovědnost. Nicméně pro J. Kotáska skutečný návrh reformy, která by měla charakter systémové reformy typické pro fázi III. - fázi systémové rekonstrukce, představovala až Bílá kniha - Národní program rozvoje vzdělávání v České republice. IV. fází tak pro J. Kotáska byla vlastní implementace navržené koncepce. $V$ návaznosti na J. Kotáska jsme také detailněji popsali transformaci vzdělávání v textu o České republice v čísle Orbis scholae 2/2007 (viz Greger; Walterová 2007). J. Kotásek, hlavní autor Bílé knihy, pak ve svém vůbec posledním textu, ve kterém bilancuje naplňování cílů Bílé knihy po pěti letech (Kotásek 2006), si byl vědom nástrah implementační fáze. Shrnuje je následujícím způsobem: „Největším nebezpečím implementační politiky, zejména pokud jde o systémové změny, je jejich celkové zpochybnění, vypuštění jejich vzájemně závislých článků, radikální změna v jejich načasování, oslabení politické podpory. Implementační proces má naději na úspěch, pokud má jednoznačnou centrální a regionální záštitu, veřejnou, mediální a zejména profesní podporu."

Příčiny nedostatečné implementace jsme pak analyzovali podrobně i s delším časovým odstupem - viz Straková et al. 2009. Poukázali jsme na skutečnost, že jisté nedostatky byly i v dokumentu samotném, který nestanovoval jasné priority (Bílá kniha je spiše doporučením všeho dobrého), mnohá opatření nebyla rozpracována dostatečně na to, aby mohla být implementována (např. v prípadě plošného testování v 5. a 9. ročníku nebo státní maturity nebyly jasně formulovány cíle testování, typy nástrojů, rizika $s$ tím spojená apod., což v prípadě především státní maturity vedlo k prosazování různých zájmů a neustálým proměnám cílu a podoby reformované maturitní zkoušky) a cíle nebyly vyjádřeny v podobě, která by umožňovala vyhodnocení jejich splnění (nebyly stanoveny indikátory naplnění cíle). Stejně tak chyběla politická stabilita, na jejíž potřebnost upozorňoval i J. Kotásek, a neustálé střídání ministrů ke zdařilé implementaci reforem také nepřispělo. Celkově tak chybělo jasné strategické rízení ze strany ministerstva. Podívejme se však zpět na teoretický rámec a jeho čtyři fáze $s$ odstupem dalších let, které již J. Kotásek sám reflektovat nemohl.

\section{JE POST-SOCIALISTICKÁ TRANSFORMACE ZAVRŠENA?}

Důležité je si položit otázku, co by mělo následovat v teoretickém rámci po případné úspěšné implementaci. Jaká by byla 5 . fáze post-socialistické transformace? Nebo by $v$ prípadě úspěšné implementace nastal konec systémové reformy a post-socialistická transformace by byla završena? A jak vypadá úspěšná implementace takové reformy, zvláště ve chvíli, kdy jako $v$ ČR nebyly jasně stanovené měřitelné cíle, které by usnadnily vyhodnocení úspěšnosti, či neúspěšnosti plánovaných změn?

Podívat se na uvedené dokumenty s odstupem času může být užitečný směr pro další bádání i porozumění vývoji českého vzdělávání v devadesátých letech. Především pak odlišné dưrazy v jednotlivých koncepcích mohou poodkrýt odlišnosti v názorech na směřování českého školství různých skupin odborníků, které patrně přetrvávají dodnes. 
Jak ukazuje celá řada studií, není ani přiliš jednoduché určit počátek post-socialistické transformace (jak společenské, tak v oblasti vzdělávání). Zatímco v Mad’arsku a Polsku můžeme sledovat jisté uvolnění již koncem osmdesátých let 20. století, kam zdejší autoři zpravidla kladou počátek transformace, v Československu $k$ větším proměnám začalo docházet až skutečně s pádem "starého režimu“ v listopadu 1989. Nicméně ještě obtížnější je určit konec post-socialistické transformace ve vzdělávání. Autoři všech studií o post-socialistické transformaci vzdělávání, jak z počátku devadesátých let 20. století, tak na počátku nového milénia, jakož i v naší knize, která zahrnuje čtyři prípadové studie (Greger; Walterová, v tisku), docházejí k závěru, že proces ještě nebyl ukončen a že nebylo dosaženo fáze systémové reformy. Na druhou stranu je však zapotřebí položit si otázku, zda je vůbec možné očekávat nějaký konec. Zda onen konec transformace v nedohlednu není jen projevem touhy po ideálu, který nikde nenastal (nejen v transformujících se zemích střední a východní Evropy, ale ani ve stabilních demokraciích).

Zajímavé je, že ani samotný tvưrce teorie změny v zemích střední a východní Evropy, Cesar Birzea, nedošel k vyřešení otázky konce reforem. Birzea popsal vývoj v Rumunsku s využitím čtyř fází, jak jsme je popsali výše, již v roce 1994. Když v roce 2003 pak znovu měl popsat vývoj v Rumunsku již s větším odstupem pro knihu M. Fullana (Birzea; a Fartusnic 2003), opět použil uvedené čtyři fáze s tím, že poslední fázi nazval „pokračování strukturálních změn a hledání systémové reformy“. Poslední fáze dle Birzey trvala od roku 1996 do roku 2000. Když pak Birzea (2008) znovu přišel $s$ analýzou post-socialistického vývoje $v$ textu před dvěma roky na stránkách tohoto časopisu, pomáhá si spíše hledáním nového počátku, hypotézou o druhé tranzici, kterou vidí v přístupu zemí do EU v dalších fázích jejího rozšiření v roce 2004 a 2007 (Rumunsko a Bulharsko).

Jak je vidět, pro autory není jednoduché přijít s určením konce transformace. Jako by vlastním jádrem změn byla především raná fáze revolučních změn, proměn bez koncepcí a plánů, otevřenosti systému a souhry aktérů na všech úrovních, která neměla obdoby $v$ systémech tradičně stojících na piliřích demokracie. Vše ostatní pak je již standardní úsilí o změnu, která je tu lépe, či hưře připravena, vyargumentována, sdílena různými aktéry (fáze iniciace $M$. Fullana), v různé míře a podobě je pak implementována (druhá Fullanova fáze) a prípadně se uchytí natrvalo v systému a přináší efektivní výsledky, především ve vztahu k učení žáků (institucionalizace), nebo zaniká.

Jako vhodné se mi tak jeví spojit Fullanův model tří-I s prvotními fázemi Birzeovy teorie post-socialistické transformace. Pro chápání proměn a reforem vzdělávání v zemích bývalého Východního bloku je zapotřebí vzít v potaz charakter revolučních změn a potřebu vymezit se vůči předchozímu společenskému uspořádání socialistické společnosti. Jedná se o fázi dekonstrukce. Ta byla celospolečenská a vedla k nastolení běžných mechanismů fungování demokratických společností, nastavení nového legislativního rámce, svobody volby a politického uspořádání, ve kterém se již prosazovaly různé protichůdné vize cílů a podoby vzdělávání nejrůznějších zájmových skupin. Nějakou dobu trvalo, než se vypracovaly první koncepce a plány rozvoje (rovněž po nutném překonání odporu k centrálnímu plánování sociali- 
stického hospodářství), což je v teoriích z východní Evropy označováno za období parciální stabilizace a rekonstrukce. Nicméně z mého pohledu je možné (a užitečné) de facto rozdělit vývoj na dvě fáze:

I. fáze: Revoluční změny a nastavení rámce pro tvorbu vzdělávací politiky odpovídající západním demokraciím.

II. fáze: Úsilí o systémovou reformu. Tu však již je užitečné popisovat s využitím Fullanova modelu tří-I, tj. iniciace, implementace a institucionalizace, a analyzovat príčiny prípadného úspěchu, či neúspěchu reformy.

Z tohoto hlediska pak je možné bud' považovat transformaci za ukončenou fázi l. a říci, že dnes již fungujeme ve standardním režimu jako ostatní země a procházíme transformací širší globálně-společenskou, které podléhají všechny společnosti, nikoliv již však transformací post-socialistickou. Připomeňme, že mezi transformace širši r radím jak transformaci Birzey nazvanou "Zpět do Evropy“, tak transformaci na cestě ke společnosti vědění.

$\mathrm{Na}$ druhou stranu je však pravděpodobně také do jisté míry legitimní názor, že post-socialistická transformace dosud neskončila. $V$ tomto př́padě však by bylo dobré, kdyby zastánci tohoto názoru přišli s definicí konce, který máme očekávat. Zatím se vždy konec skrýval za obecné pojmy systémová reforma, které však nebyly jasně definovány. Jinak je samozřejmě možné, že se stále budeme setkávat s myšlenkou post-socialismu či post-komunismu (a lze pro ni nalézt také řadu odůvodnění), stejně jako se setkáváme stále s ideou dalších post-stavů: např. post-kolonialismus ${ }^{5}$, post-apartheidismus, post-moderna. Nepochybně nás koncepce „post-uvažování vrací k historickým souvislostem a skutečnosti, že změny jsou vskutku závislé na předchozích konfiguracích společenského uspořádání (path dependency). Bez porozumění minulosti pak nemůžeme dostatečně chápat změny, které se udály. Na druhou stranu však porozumění neúspěchu reforem v České republice může být užitečnější analyzovat $z$ hlediska přístupů nezatížených srovnáním s dobou před listopadem 1989, například Fullanovým modelem tří-I. V tomto světle vysvitnou chyby, kterých jsme se dopustili my sami, a nikoliv pouze chyby, které se přenášejí z minulosti. Vzrůstá tak naše odpovědnost za stav věcí budoucích, což je v době špatných výsledků našeho školství jistě velmi potřebné. Jistou naději v tomto ohledu skýtají nedávné studie, které př́íčiny zhoršování výsledků českých žáků analyzují a navrhují jisté směry nápravy (Straková et al. 2009, McKinsey 2010). Nicméně od těch je zapotřebí se vydat $k$ pečlivě zpracovanému návrhu změn, s promyšlenou implementací a jejím řízením.

5 Za podnět odpovědět si na otázku konce post-socialistické transformace srovnáním se stavem dalších „post-stavů“ v odlišných částech světa děkuji Alexi Wisemanovi, při neformální diskusi i jeho účasti a zajímavém pohledu na post-socialistickou transformaci v rámci kulatého stolu věnovaného tomuto tématu na mezinárodní konferenci v Praze v záŕí 2010. 


\section{ZÁVĚR}

V tomto textu jsem předložil čtenářům dvě konkurenční teorie post-socialistické transformace vysvětlující změny ve vzdělávání od pádu železné opony - Fullanův model tří-I a Birzeovu koncepci post-socialistické transformace vzdělávání. Obě teorie byly testovány na případech řady zemí "Východního bloku" a na základě jejich kritického rozboru jsem došel k formulaci vlastní teorie post-socialistické transformace, která kombinuje výhody obou modelů. Z Birzeova modelu jsem využil především ranou fázi spontánních změn, které se udály v několika málo letech po pádu komunistického režimu v zemích "Ostbloku“. Tyto považuji za 1. fázi transformace. Nicméně další vývoj v zemích Východního bloku se pak již jeví jako lépe interpretovatelný pohledem tří fází zavádění plánovaných reforem, jak je popsal M. Fullan $v$ modelu tří-I. Kombinace obou modelů se pak jeví jako vhodný teoretický model pro popis vývoje vzdělávání v uplynulých 20 letech nejen v ČR, ale i v dalších post-komunistických zemích. $V$ textu jsme rovněž odmítli spojovat post-socialistickou transformaci s dalšími velkými transformacemi - evropskou integrací či transformací ke společnosti vědění. Charakter těchto transformací je odlišný tím, že nemají 1. fázi spontánních reforem a „změn, které se udály přes noc".

Navíc oddělení 2. fáze post-socialistické transformace umožňuje plastičtěji analyzovat neúspěchy 20 let reformování v ČR. S využitím modelu tří- je možné analyzovat př́klady nepovedených reforem, včetně reformy kurikulární - kde byla podceněna jak fáze iniciace (nedostatečné vysvětlení reformy učitelům, ale i rodičům a širší veřejnosti, nebyly definovány měřitelné cíle, ke kterým má reforma vést), tak fáze implementace (nedostatečná podpora školám $v$ zavádění reforem, např́klad také neexistence modelových programů, personální a finanční podpora školám aj.). Analýza, která by dokládala tvrzení o tom, že se obě fáze nepodařilo dobře realizovat, a proto považuji kurikulární reformu za nepovedenou, by vydala na samotný rozsáhlý text, a představuje tak výzvu pro další práci mou, nebo dalších kolegů či kolegyň.

Další směr, kterým se může výzkum post-socialistické transformace dále rozvíjet, je především detailnější popis samotného procesu transformace v ČR založený na analýze pramenů a dílčích koncepcí vzdělávání, které se objevily v devadesátých letech 20. století, či s využitím pamětí aktérů změn na různých úrovních. Taková práce je však výzvou spíše pro historické bádání s důrazem na přesnost a korektnost zpracování pramenů. Zvláště se nabízí využití orální historie pamětníků, kteří jsou stále mezi námi. Toto téma by vydalo na nejednu disertační práci.

Svým textem jsem se snažil poukázat na skutečnost, že interpretace nedávné minulosti může vést $k$ poučení pro současnost. Tento text tak končím $s$ nadějí, že bude doplněn dalšími autory o analýzy české cesty $v$ různých oblastech vzdělávání (např. v kurikulární oblasti, vývoj v oblasti evaluace, učitelského vzdělávání a profesního rozvoje aj.). Snad i model tří-l, který jsem v textu představil, může být pro mnohé autory inspirativním rámcem analýz. Především však doufám, že text přispěl $k$ tomu, abychom si uvědomili dvě základní věci: 1) jakákoliv změna musí přesně definovat své cíle a musí je dobře komunikovat navenek (fáze inciace); 2) 
bez dobře promyšlené a řádně financované podpory školám v zavádění změn žádná reálná změna nenastane (fáze implementace).

\section{LITERATURA}

BERRYMAN, S. E. Hidden Challanges to Education Systems in Transition Economies. Washington : The World Bank, 2000.

BîRZEA, C. Educational Policies of Countries in Transition. Strassbourg : Council of Europe Press, 1994.

BÎRZEA, C. Educational Reform and Educational Research in Central-Eastern Europe: The Case of Romania. Paper presented on IBE International meeting on "Educational Reform and Educational Research. Tokyo, Japan, September 1995.

BÎRZEA, C. Educational Reform and Power Strugles in Romania. European Journal of Education, 1996a, roč. 31, č. 1, s. 97-107.

BÎRZEA, C. Reformní proces ve školství transformujicích se zemí střední a východní Evropy. In Reformy školství ve střední a východní Evropě. Praha : Ústav pro informace ve vzdělávání, 1996b.

BIRZEA, C. Back to Europe and the second transition in Central Eastern Europe. Orbis scholae, 2008, roč. 2, č. 2, s. 105-113.

BÎRZEA, C.; FARTUSNIC, C. Reforming the Romanian System of Education. In POLYZOI, E.; FULLAN, M.; ANCHAN, J. P. (Eds.). Change Forces in Post-communist Eastern Europe: Education in transition. London : RoutledgeFalmer, 2003, s. 74-93.

ČERYCH, L. Educational Reforms in Central and Eastern Europe. European Journal of Education, 1995, roč. 30, č. 4, s. 423-435.

DAVIDOVÁ, E.; LHOTKA, P.; VOJTOVÁ, P. Právní postavení Romů v zemích Evropské unie. Praha :Triton, 2005.

FISZBEIN, A. Decentralizing Education in Transition Societies: Case Studies from Central and Eastern Europe. Washington :The World Bank, 2001.

FULLAN, M. The New Meaning of Educational Change. (4th edition). New York : Teachers College Press, 2007.

FULLAN, M.; LEVIN, B. The Fundamentals of Whole-System Reform: A Case Study From Canada. Education Week, 2009, roč. 28, č. 35, s. 30-31.

GREGER, D.; WALTEROVÁ, E. In Pursuit of Educational Change: Transformation of Education in the Czech Republic. Orbis scholae, 2007, roč. 1, č. 2, s. 11-44.

GREGER, D.; WALTEROVÁ, E. (Eds). Towards Educational Change: The Transformation of Educational Systems in Post-Communist Countries. New York: Routledge ( $v$ tis$\mathrm{ku})$.

HALÁSZ, G. Educational Change and Social Transition in Hungary. In POLYZOI, E.; FULLAN, M.; ANCHAN, J.P. (Eds.). Change Forces in Post-communist Eastern Europe: Education in transition. London: RoutledgeFalmer, 2003, s. 55-73.

HALÁSZ, G. From Deconstruction to Systemic Reform: Educational Transformation in Hungary. Orbis scholae, 2007, roč. 1, č. 2, s. 45-79.

KOSOVÁ, B.; PORUBSKÝ, Š. Slovenská cesta transformácie edukačného systému 
po roku 1989 na príklade primárneho vzdelávania a prípravy jeho učitel'ov. Pedagogická orientace, 2011, roč. 21, č. 1, s. 35-50.

KOTÁSEK, J.; GREGER, D.; PROCHÁZKOVÁ, I. Demand for Schooling in the Czech Republic (Country Report for OECD) [online]. Paris: OECD, 2004 [cit. 2011-02-24]. Dostupné na WWW: <http://www.oecd.org/dataoecd/38/37/33707802.pdf>.

KOTÁSEK, J.Vzdělávací politika a rozvoj školství v České republice po roce 1989 - 1. Čast'. Technológia vzdelávania, 2005a, č. 3, s. 7-11.

KOTÁSEK, J. Vzdělávací politika a rozvoj školství v České republice po roce 1989 - pokračovanie. Technológia vzdelávania, 2005b, č. 3, s. 7-11.

KOTÁSEK, J. Bílá kniha po pěti letech. Učitelské listy, 23.2.2006 [online] [cit. 24. února 2011]. Dostupné na WWW: <http://www.ucitelske-listy.cz/2009/11/jiri-kotasek-bila-kniha-po-peti-letech.html>.

MACHONIN, P. Česká společnost a sociologické poznání. Problémy společenské transformace a modernizace od poloviny šedesátých let 20. století do současnosti. Praha : ISV nakladatelství, 2005.

McKINSEY \& Company. Klesající výsledky českého základního a středního školství: fakta a řešení. Praha, záŕí 2010 [online] [cit. 23. února 2011]. Dostupné na WWW: <http://www.mckinsey.com/locations/prague/work/probono/2010_09_02_ McKinsey\&Company_Klesajici_vysledky_ceskych_zakladnich_a_strednich_ skol_fakta_a_reseni.pdf $>$.

MAYS, A.; POLYZOI, E.; GARDNER, S. Educational Transformation in the Czech Republic since 1989: Can A North American Model of Educational Change Be Applied? Paper presented at the AERA, April 8-12, 1996, New York.

MCLEISH, E.; PHILIPS, D. (Eds.). Processes of Transition in Education Systems. Oxford : Oxford Studies in Comparative Education, Volume 8(2). Symposium Books, 1998.

PRŮCHA, J.; WALTEROVÁ, E. Education in transition: Czechoslovakia. Praha : H\&H vydavatelství, 1992.

POLYZOI, E.; ČERNÁ, M. Forces Affecting the Implementation of Educational Change in the Czech Republic. In POLYZOI, E.; FULLAN, M.; ANCHAN, J. P. (Eds.). Change Forces in Post-communist Eastern Europe: Education in transition. London : RoutledgeFalmer, 2003, s. 34-54.

STRAKOVÁ, J.; GREGER, D.; KALOUS, J.; KOŠŤÁLOVÁ, H.; POLECHOVÁ, P.; SIMONOVÁ, J.; ŠTEFFL, O.; VESELÝ, A. Analýza naplnění cílů Národního programu rozvoje vzdělávání v České republice (Bílé knihy) v oblasti předškolního, základního a středního vzdělávání. Praha: MŠMT, 2009 [online] [cit. 22. února 2011]. Dostupné na WWW: <http://www.davidgreger.cz/images/pdf_files/msmt-zprava-evaluace_bk.pdf $>$. 